\title{
The Role of Prophetic Leadership on Workplace Spirituality At sufism-based Islamic Boarding School
}

\author{
Irfan Budiono \\ Universitas Negeri Jakarta \\ Email: irfanbudiono_im16s3@mahasiswa.unj.ac.id \\ Hamidah \\ Universitas Negeri Jakarta \\ Mahmuddin Yasin \\ Universitas Krisnadwipayana
}

\begin{abstract}
The purpose of this study is to analyze the effect of prophetic leadership on the workplace spirituality among officials and employees in an Islamic boarding school. This quantitative research used data collection through a survey, in a form of a set of questionnaire, in the Sufism-based Islamic boarding school in Tasikmalaya, Indonesia. The study sample consisted of 270 officials and employees of the boarding school. The data was analyzed using SEM with the AMOS 24 program, to test the effects. The research findings showed a significant effect of the prophetic leadership on the workplace spirituality. Originality of this research on the unit analysis of officials and employees at the sufism-base Islamic boarding school.
\end{abstract}

Keywords: : prophetic leadership, workplace spirituality, and sufism-base Islamic boarding school

Received: 28 February 2020;

Accepted: 15 April 2020;

Publish; June 2020.

How to Cite:

Budiono, I., Hamidah, Yasin, M. (2020). The Role of Prophetic Leadership on Workplace Spirituality At sufism-based Islamic Boarding School. Journal of Business and Behavioural Entrepreneurship, 4(1), 122-129. https://doi.org/10.21009/ JOBBE.004.1.09 


\section{INTRODUCTION}

Pesantren, a typical Islamic education from Indonesia, has grown significantly. In 1977 , there were 4,195 pesantrens nationwide. It grew up to 11,312 pesantrens in 2001 and 14,798 in 2005. By 2014, it has been 28,194 pesantrens (Directorate General of Islamic Education, 2014).

A pesantren is usually led by a Kyai, or Shaykh, a central figure who has a distinguished leadership style compared to common leadership styles in any other education institutions. Kyai's leadership is shaped by Islamic leadership style that refers to the way the Prophet led i.e. Prophetic Leadership. Hamid (2017) mentioned a term of prophetic leadership, by which innovation process occurs in pesantren (Hamid \& Juliansyahzen, 2017).

According to Ramadhana (2008), one of the characteristics of the prophetic leadership is a combination of participative, charismatic and transformational leadership (Ramadhana, 2008). In line with the view from Ramadhana, another research by Asy'ariy (2018) mentioned that the advantages of transformational, visionary and situational leadership can be seen in the practice of prophetic leadership. In contrary, contiguity of the above is also found in the prophetic leadership (Asy'ariy, 2018).

According to Maheran (2015), prophetic leadership expands the point of view of leadership and provides a richer and in-depth understanding about a relationship between a leader and followers in relation to the quality of decision-making process. Prophetic leadership explores literatures on the life of the Prophet and describes a theoretical relationship between personal characters and spiritual leadership (Maharen Nik Muhammad, 2015). Ramadhana (2008) also mentioned that prophetic leadership is supported by spiritual authority (Ramadhana, 2008). According to Tobroni (2015), a spiritual leader has an ultimate commitment, dedication and integrity and is based on absolute values. Ethics of the spiritual leadership is as seen as the practice by the Prophet, based on Quran (Tobroni, 2015).

According to Naidoo (2014), a workplace spirituality may lead to a spiritual leadership that allows employees and leaders act based on personal truths, integrity, values and ethical practices (Naidoo, 2014). Ayranci and Samercios (2011) analyzed that spirituality has a significant relationship with spiritual leadership. This relationship is stronger that the relationship between spiritual leadership and spiritual and religious factors (Ayranci \& Semercioz, 2011). Referring to views from Maheran, Ramadhana and Tobroni, it is concluded that there is a positive relationship between prophetic leadership and workplace spirituality.

Many pesantren have distinctive characteristics, one of which is sufism-based education. This characteristic is promoted by sufism organization named Tariqa. A tariqa, originally a form of individual piety in a modest and exclusive bond between a sufi master and its followers, has structurally developed into a form of a complex religious institution. There are tariqas that structurally expands their educational forms into a pesantren (Riyadi, 2014). A strong bond between sufi master (mursyid) and its followers is the main pillar for the tariqa and creates a top-down organization. Such relationship is seen negatively as it is perceived to obstruct a modernization of a pesantren. This perception emerges some some reasons, first, tariqa imposes individual cult; second, such cult creates taqlid as the followers devotes their life to their master. Such relationship is perceived to provide a narrow space for freedom, creativity and initiative from sub-ordinates.

A Sufism-based pesantren provides contributions to the quality of human resources through a sufism education. A strong bond between a Sufi master and its fol- 
lowers, and dominance of a Sufi master creates a negative impression on the workplace spirituality of the educators on the boarding school. This condition refers to the definition of workplace spirituality ie : feeling completeness and joy (Giacalone, 2015); meaningful works (Ashmos and Duchon, 2000); opportunity to strengthen health and spiritual well-being (Lee, Richter, \& McGuire, 2013); create loyalty and productive (Hicks, 2003), which of course is influenced by a leader, while Pesantren leadership is prophetic leadership (Hamid, 2017). So, it is very important to know the influence of prophetic leadership on spirituality at work, as well as in order to prove the truth of the negative impressions that emerge.

Referring to the above narration, the objective of this research is to understand the influence of the prophetic leadership on the workplace spirituality in a sufism-based pesantren. The fact that there is no simil.

\section{LITERATURE REVIEW}

\section{Prophetic Leadership}

Prophetic leadership is theoretically based on the life of the Prophet. It is a leadership style that leads to all aspects and elements in life and builds mutual relationship between leader and followers (Maheran Nik Muhammad, 2015). Prophetic leadership is a process to influence others in order them to sincerely follow the directions with loyalty as a reflection of their obedience, fear and faith toward Allah SWT (AdhDzakiey, 2009). Prophetic leadership, such as what has been done to the prophets, is the ability to influence others to sincerely achieve common goals. The process of influence is executed by examples, through four characteristics, namely Sidiq (integrity), amanah (accountable, trustworthy), tabligh (emphatic and effective communication) and fathonah (intelligent) (Budiharto \& Himam, 2006). Prophetic leadership also shows leadership relationships and social network theory, the need to find common ground and synergy between leaders and followers (Maheran NM \& Akbarzadeh, 2013). Prophetic leadership is the concept of leadership from the Prophet that consists of the behaviours and attitudes of the leader (Hadi HM, 2012). Prophetic leadership should be based on three foundations: grace, kindness, and justice. (Ali, 2009).

\section{Workplace Spirituality}

Workplace Spirituality is a dynamic factor in building trust between management and employees (Alas \& Mousa, 2016). Workplace spirituality is defined as a framework of values of individuals or organizations that introduce transcendental experience of employees through work processes and a way to facilitate a connected sense to others in a way that gives a feeling of completeness and joy (Giacalone, 2015). Workplace spirituality is a recognition by employees whose inner life is nourished by meaningful works within the community (Ashmos and Duchon, 2000). Workplace spirituality is the psychological climate in a workplace. This condition is due to people (workers) see themselves maintained meaningful jobs, so that the work unit is filled with a high spirituality (Duchon and Plowman, 2005). Feelings regarding the settlement relationships with self and others refer to as the dimensions of workplace spirituality (Mitroff \& Denton, 1999). Workplace Spirituality is workplace conditions where a person has opportunity to strengthen their health and spiritual well-being (Lee, Richter, \& McGuire, 2013). Workplace spirituality is often used to create loyalty and productive workers (Hicks, 2003). Modern workers experience personal spirituality at 
workplace as they feel the presence of an impersonal power in its work and recognize the existence of a higher power beyond one's immediate experience that supports the activities of the job (Solomon, 2005).

\section{The effect of prophetic leadership on workplace spirituality}

Servicing leadership has a positive and real linkage with the workplace spirituality (Khan, Khan, and Chaudhry, 2015). The effectiveness of leadership based on workplace spirituality is interconnected with and has a positive impact on the performance of employees (Sukanya, 2014).. There is a positive correlation between transformational leadership and workplace spirituality (Majeed, Mohd Nor and Mohd Mustamil, 2017). Spiritual Leadership had a positive and significant effect on workplace spirituality (Jufrizen, Sari, Nasution, Radiman, \& Wahyuni, 2019), The above arguments lead to an interim conclusion that The prophetic leadership provides a directly positive influence on the workplace spirituality.

\section{RESEARCH METHOD}

\section{Sample and Data collection}

The study uses a survey method using analysis techniques of Structural Equation Model (SEM), by AMOS 24 program and the maximum likelihood estimation approach. The sample in this study includes 273 employees and officials in Idrisiyyah boarding school. The sampling technique is a probability sampling using simple random sampling, regardless of the strata in the population.

\section{Measures}

All constructs in the study was measured using Likert scale (Likert scale), with a range of values from 1 to 5 . The range is between "Strongly Disagree" $(\mathrm{SD})=1$ up to "Strongly Agree" (SA) $=5$ in order to measure the construct of the workplace spirituality. The prophetic leadership is measured using following indicators: self control, influencing others with sincere, provide direction (soul, qolbu, reasonable thought, body and behaviour through exemplary characteristics of sidiq, amanah, tabligh, and fathonah (Budiharto \& Himam, 2006; Adz-Dzakiey, 2009; Munardji, 2016). The workplace spirituality is measured using following indicators: recognition has an inner life is nourished, feel the meaning in work, making productive workers, giving a sense of joy and completeness, and acknowledge the role of God (Ashmos \& Duchon, 2000; Duchon \& Plowman, 2005; Hicks, 2003; Giacalone, 2004; Solomon, 2005).

\section{RESULTS AND DISCUSSIONS}

The test results (see table 1) show that the model full model can be categorized meet the criteria of fit, it's based criteria have been fulfilled several criteria of goodness of fit. The results of chi-square test calculations in obtaining a full model chi-square value of 105,412 is still above the chi-square table for 76 degrees of freedom at a significant level of $1 \%$ at 107,58 . A probability value of 0.014 which is above value of 0.01. Value CMIN / DF amounted to 1,387 is still below value 2,00. GFI value of 0.937 (Good), above 0.90 ;. AGFI value of 0.916 (good) still above 0,9 ; TLI value of 0.9985 (good) above 0.90 . CFI value of 0.988 (good) which value is above 0.90 and below RMSEA value of 0.041 (good) which is below to the value of 0.08 . 


\section{Table 1. Goodness of Fit}

\begin{tabular}{|l|l|l|l|l|l|l|}
\hline Model & GFI & AGFI & TLI & CFI & RMSEA & $\begin{array}{l}\text { CMIN / } \\
\text { DF }\end{array}$ \\
\hline default models &, 939 &, 916 &, 985 &, 988 &, 041 & 1,387 \\
\hline
\end{tabular}

Value factor loading all indicators (see table 2) show the estimated value of which is in the range of 0.725 and 0.887 value. This means that this value is above the limit value of 0.5 is used as the criteria, so the model is considered fit and able to continue to the next test. Based on the results of variance extract and the reliability contruct obtained variance extract value 0.687 , for the leadership prophetic and 0.594 for workplace spirituality As for reliability contruct, the value of 0.952 for prophetic leadership, and 0.879 for workplace spirituality . Value of Variance extract and the reliability contruct obtained showed a good value, which implies there are indicators that can explain the construct.

Table 2. Standardized Regression Weights

\begin{tabular}{|l|l|l|r|r|l|l|r|}
\hline & & & estimate & & & & estimate \\
\hline WPS & $<---$ & PL &, 689 & X8 & $<---$ & PL &, 725 \\
\hline X1 & $<---$ & PL &, 763 & X9 & $<---$ & PL &, 782 \\
\hline X2 & $<---$ & PL &, 832 & X10 & $<---$ & WPS &, 732 \\
\hline X3 & $<---$ & PL &, 805 & X11 & $<---$ & WPS &, 729 \\
\hline X4 & $<---$ & PL &, 887 & X12 & $<---$ & WPS &, 737 \\
\hline X5 & $<---$ & PL &, 828 & X13 & $<---$ & WPS &, 808 \\
\hline X6 & $<---$ & PL &, 826 & X14 & $<---$ & WPS &, 840 \\
\hline X7 & $<---$ & PL &, 854 & & & & \\
\hline
\end{tabular}

$\mathrm{PL}=$ Prophetic Leadership, WPS $=$ Workplace Spirituality

Table 3. Variance extract and reliability contruct

\begin{tabular}{|l|c|r|}
\hline \multicolumn{1}{|c|}{ variable } & reliability contruct & variance extract \\
\hline Prophetic Leadership & 0.952 & .687 \\
\hline Workplace Spirituality & 0.879 & .594 \\
\hline
\end{tabular}

Testing Statistical Hypotheses on the hypothesis of a positive relationship between the prophetic leadership on workplace spirituality, can be seen with CR values obtained from the regression weight Maximum Likelihood Estimates (see table 4). CR value with a probability of 9.075 and $* * *$. qualify for acceptance of the hypothesis, which value CR greater than 1.96 , and the probability is less than 0.05 . So there is positive and significant correlation between the prophetic leadership to workplace spirituality.

* The Role of Prophetic Leadership on Workplace Spirituality At sufism-based Islamic Boarding School. 


\section{Table 4. Summary Regression Weights}

\begin{tabular}{|c|c|c|c|c|c|c|c|}
\hline & & estimate & SE & CR & P & Label \\
\hline $\begin{array}{c}\text { Workplace Spirit- } \\
\text { uality }\end{array}$ & $<--$ & $\begin{array}{c}\text { Prophetic Lead- } \\
\text { ership }\end{array}$ &, 563 &, 062 & 9.075 & $* * *$ & par_13 \\
\hline
\end{tabular}

\section{Discussion}

The research concludes that the prophetic leadership has a directly positive influence on the workplace spirituality. This is in line with the study by Abdurrahman and Agustini (2011); Sukanya (2014) mentioned that the spiritual leadership provides a positive and significant correlation with the workplace spirituality. If the servicing leadership is also considered to lead toward a prophetic leadership, this study is also in line with the arguments by Khan, \& Chaudhry (2015) and that by Ayranci and Semercioz, 2011. It is also consistent with the opinion from Devost, 2010 that demonstrated a correlation between leadership and the workplace spirituality. It is also consistent with the view from Jiang Lin et. Al (2017). This research also strengthens a prior study by Majeed, Mohd Nor \& Mohd Mustamil (2017) that showed a fact that there is a positive correlation between transformational leadership and the workplace spirituality (Majeed at al, 2017). It is in accordance with the study by Ayranci and Semercioz (2011) that pointed a correlation between spiritual factors and spiritual leadership. This relationship is stronger that the relationship between spiritual leadership and spiritual and religious factors (Ayranci and Semercioz, 2011).

Views from previous researchers have indicated that leadership is a direct and positive influence on the workplace spirituality. The research in pesantren Idrisiyyah also showed that the prophetic leadership provides a positive influence on the workplace spirituality. This finding is in contrary with common view that leadership by a sufi master (mursyid) in a tariqa is dominant (Suyuti,1996). There is also a perception that tariqa applies an authoritatian leadership (Howell, 2001). Object of the research is a sufism-based pesantren in tariqa Idrisiyyah. Unlike any other tariqas, Idrisiyyah, originally named Sanusiyyah, is a tariqa that forms an organizional movement.

This tariqa combines a traditional tariqa leadership and professional organization. It bases its successes on 2 methods i.e. burhaniah (knowledge) and isyraqiyah (devide enlightenment). Such combination has brought tariqa Sanusiyah into a solid organization (Al-Sanusi, 2001). As a successor of Sanusiyyah, tariqa Idrisiyyah in Indonesia also applies the same organizational movement.

In contrary to stereotype, tariqa Idrisiyyah pays stronger attention on Syariah aspect than mystical aspect (Pili, 2019). Although Idrisiyyah promotes sufism-based pesantren, Idrisiyyah is not against science and technology. Idrisiyyah applies an accountable and transparent management (Priatna, Nurhamzah, Ratnasih \& Siregar, 2018). The pesantren encourages its students to learn sufism-based entrepreneurship for self-sufficiency (Suryatman, 2017).

Tariqa Idrisiyyah shows a rapid progress in institutionalization, economic development, human resource management, education and social works. It is a progressive movement that build cooperation for a better world (Basyir, 2019). Thus, Idrisiyyah is well-known as a neo sufism in Indonesia (Pili, 2019). A positive influence of the prophetic leadership on the workplace spirituality is easily seen in pesantren Idrisiyyah as the spiritual guidance by the sufi master occurs in daily life of its followers.

Sufism is taught regularly for followers, while specific topics of teachings is delivered weekly for employees and educators. Some indicators for a workplace spirituality 
such as a maintained spiritual life, feeling of a meaningful works, recognition of the precence of God in work life are amongst the topics delivered by the sufi master. Thus, the prophetic leadership by the Mursyid in pesantren Idrisiyyah has a positive correlation with the workplace spirituality for its followers and educators in the pesantren.

\section{CONCLUSION}

The research in pesantren Idrisiyyah showed that the prophetic leadership provides a positive influence on the workplace spirituality. This is in line with the study from previous researchers have indicated that leadership is a direct and positive influence on the workplace spirituality. A positive influence of the prophetic leadership on the workplace spirituality is easily seen in pesantren Idrisiyyah as the spiritual guidance by the sufi master occurs in daily life of its followers.

\section{Acknowledgment}

This research was funded with researcher's own funds and could be carried out by the contribution of many parties. The researcher would like to express deep gratitude to all parties contributed to the completion of thus research. Special thanks to the the top management of the pesantren Idrisiyyah and management board, whole parties at the boarding schools that allowed the Institution as the object of the research. Sincere thanks to the lecturers of Jakarta State University and all colleagues at the Jakarta State University, who contribute brilliant ideas to this research.

\section{REFERENCES}

Adz-Dzakiey, H. B. (2009). Kepemimpinan Kenabian (Prophetic Leadership) (Cet. Ke 1). Yogyakarta: Al-Manar.

Al-Sanusi, M. b A. (2001). Al-Tsimar Al-Zakiyah Lil Harakah Al-Sanusiyah. Kairo: Maktabah al-Tabi'in.

Alas, R., \& Mousa, M. (2016). Organizational Culture and Workplace Spirituality. International Journal of Emerging Research in Management \&Technology, 9359 (53), 2278-9359.

Ali, A. J. (2009). Islamic perspectives on leadership: a model. International Journal of Islamic and Middle Eastern Finance and Management, 2(2), 160-180. https:// doi.org/10.1108/17538390910965167

Ashmos, D. P., \& Duchon, D. (2000). Spirituality at Work: A Conceptualization and Measure. Journal of Management Inquiry, 9(2), 134-145.

Asy'ariy. (2018). Pandangan Kepemimpinan Profetik Terhadap Persinggungan Antara Kepemimpinan Transformasional, Kepemimpinan Visoner, Dan Kepemimpinan Situasional. Al Ta'dib, 7(2), 135-154.

Ayranci, E., \& Semercioz, F. (2011). The Relationship between Spiritual Leadership and Issues of Spirituality and Religiosity: A Study of Top Turkish Managers. International Journal of Business and Management, 6(4).

Basyir, D. (2019). Sambutan Buku Tarekat Idrisiyyah, Sejarah dan ajarannya. In $T a-$ rekat Idrisiyyah, Sejarah dan ajarannya. Tasikmalaya: Mawahib.

Budiharto, S., \& Himam, F. (2006). Konstruk Teoritis dan Pengukuran Kepemimpinan Profetik. Jurnal Psikologi, 33(2), 133-146.

Direktur Jenderal Pendidikan Islam. Lampiran Keputusan Direktur Jenderal Pendidikan Islam Nomor 5877 Tahun 2014 Tentang Pedoman Izin Operasional Pondok

* The Role of Prophetic Leadership on Workplace Spirituality At sufism-based Islamic Boarding School.

* $\quad$ https://doi.org/10.21009/JOBBE.004.1.09 
Pesantren., Pub. L. No. 5877 (2014).

Duchon, D., \& Plowman, D. A. (2005). Nurturing the spirit at work: Impact on work unit performance. Leadership Quarterly, 16(5), 807-833.

Giacalone, R. A., \& Jurkiewicz, C. L. (2004). A Values Framework for Measuring the Impact of Workplace Spirituality on Organizational Performance. Journal of Business Ethics, 49(2), 129-142.

Hadi HM, S. (2012). Kepemimpinan Spiritual Solusi Mengatasi Krisis Kepemimpinan Pendidikan Islam. Lisan Al-Hal, 4(1), 25-50.

Hamid, N., \& Juliansyahzen, M. I. (2017). Prophetic Leadership in Pesantren Education: Study at Pondok Pesantren Universitas Islam Indonesia. Jurnal Pendidikan Islam, 6(2), 349. https://doi.org/10.14421/jpi.2017.62.349-369

Hicks, D. A. (2003). Religion And The Workplace (First publ). Cambridge, United Kingdom: cambridge university press.

Howell, J. D. A. Y. (2001). Sufism and the Indonesian Islamic Revival. The Journal of Asian Studies, 60(3), 701-729.

Jufrizen, Sari, M., Nasution, M. I., Radiman, \& Wahyuni, S. F. (2019). Research in Business and Social Science The strategy of Spiritual Leadership: The Role of Organizational Commitment at Private Universities. International Journal of Research in Business and Social Science, 8(1), 64-72.

Lee, S. M., Richter, L., \& McGuire, S. M. (2013). Ascension Health and Workplace Spirituality: Strong Foundation, Sustainable Future. In Handbook of Faith and Spirituality in the Workplace. https://doi.org/10.1007/978-1-4614-5233-1

Maheran N M, N., \& Akbarzadeh, S. (2013). Prophetic Leadership and Financial Decision Making Quality: Partial Least Square ( PLS ) Path Modeling Analysis . International Journal of Business and Management Studies, 2(1), 195-213.

Maheran Nik Muhammad, N. (2015). Prophetic Leadership Model : Conceptualizing a Prophet's Leadership Behaviour, Leader - Follower Mutuality and Altruism to Decision Making Quality. European Journal of Interdisciplinary Studies, 3(1), 93 $-106$.

Majeed, N., Mohd Nor, M. N., \& Mohd Mustamil, N. (2017). Exploring Relationship Between Transformational Leadership and Organizational Citizenship Behaviors Through Lens of Workplace Spirituality. International Online Journal of Educational Leadership, 1(1), 5-33.

Mitroff, I. I., \& Denton, E. a. (1999). A study of spirituality in the workplace. Sloan Management Review, 40(4), 83-92.

Naidoo, M. (2014). The potential of spiritual leadership in workplace spirituality. Koers - Bulletin for Christian Scholarship, 79(2), 1-8.

Pili, S. B. (2019). Tarekat Idrisiyyah, Sejarah dan ajarannya. Tasikmalaya: Mawahib.

Priatna, T., Nurhamzah, Ratnasih, T., \& Siregar, H. S. (2018). Educational financing management in tarekat - based pesantren. Jurnal Pendidikan Islam, 4(1), 63-74.

Ramadhana, R. (2008). Prophetic Leadership, Membentuk Pribadi Para Nabi Berbasis Spiritual. Yogyakarta: Diva Press.

Riyadi, A. (2014). Tarekat sebagai Organisasi Tasawuf (Melacak Peran Tarekat Dalam Perkembangan Dakwah Islamiyah). At-Taqaddum: Jurnal Peningkatan Mutu Keilmuan Dan Kependidikan Islam, 6(2), 359-385.

Solomon, J. (2005). Spirituality at Work Seth Wax. GoodWork ${ }^{\circledR}$ Project Harvard University, (41), 1-31.

Suyuti, A. (1996). Percik-percik Kesufian. Jakarta: Pustaka Amani.

Tobroni. (2015). Spiritual leadership: a solution of the leadership crisis in islamic education in indonesia. British Journal of Education, 3(11), 40-53.

* The Role of Prophetic Leadership on Workplace Spirituality At sufism-based Islamic Boarding School.

* $\quad$ https://doi.org/10.21009/JOBBE.004.1.09 